\title{
Resolute Ambivalence: Why Judiciaries Do Not Institutionalize Their Decision Support Systems ${ }^{1}$
}

\author{
CYRUS TATA
}

\begin{abstract}
This article considers why judiciaries appear to be reluctant to institutionally legitimate judicial decision support systems. While representation of decision processes, design, judicial ownership, the apparent neutrality of data, and 'choice' are all crucial to allaying judicial concern about embracing technological support, it is suggested here that the deepest concern lies in the judicial discourse of 'balance' between formal and substantive visions of justice. Outlining the development of aggregate decision support systems, the article considers the case of New South Wales, which has the longest established judicial decision support system. Revealing a marked judicial ambivalence either to endorse officially, or, to dismiss that system the paper asks whether this ambivalence is simply a symptom of a deeper malaise, namely a 'jurisprudential incoherence' in judicial decisionmaking. Examining the notion of 'jurisprudential incoherence' in judicial thought and behaviour, the article reveals that the assumed 'incoherence' of judicial behaviour stems from a fixation with normative-philosophical justifications for judging, which are also convenient to mechanistic thinking about computerized decision support. For some scholars the supposed problem of 'jurisprudential incoherence' can be challenged by greater transparency in judicial reasoning and accountability. Turning to liberal-legal models of accountability, the paper proposes instead that accountability is an inescapably social practice and that the search for a moral-philosophically coherent judicial 'explanation' of the discretionary judicial decision process is inevitably and necessarily elusive.
\end{abstract}

\section{Introduction}

Despite the now well-established tradition of using computer technology to support substantive discretionary judicial decision-making (e.g. Hogarth, 1971; Doob and Park, 1987; Potas et al., 1998; Hassett, 1993; Hutton et al., 1995; Tata, 1998; Zeleznikow and 
Stranieri, 1998), progress towards the institutionalization of such technology has barely progressed (Leith, 1998; Oskamp, 1995). By 'institutionalization' in this context, I specifically mean institutional support and especially legitimation from official judicial institutional authority. While 'decision support' systems are increasingly part of the official fabric of many legal organizations (e.g. Wall and Johnstone, 1997), judicial decision-making seems to remain relatively impervious to this trend. This article explores why judiciaries remain both most 'in need' of support and yet at the same time most uncomfortable with the idea of institutionalising such support.

At first blush, explanations for judicial reluctance to embrace decision support systems might seem straightforward. For example, judges world-wide intensely value their 'independence' (Malleson, 1999) and 'ownership' of 'their discretion' (Ashworth, 1995; Tata, 1998). Yet, as we shall see, even where judges initiate and feel a strong sense of ownership of 'their' own system (if only as a bulwark against threats to their cherished notion of judicial independence), there is still deep reluctance to institutionalize their own judicial decision support system.

Another obvious explanation might be that judicial decision support systems by their nature address decisions where there are no 'right' or logically deducible solutions. This might be part of the reason why there has been very limited judicial desire to pursue into full operation some (Tata, 1998), perhaps all (Leith, 1988), artificial intelligence approaches. However, even where judiciaries accept the apparent legal or ideological neutrality of decision support systems (i.e. where they accept such systems as simply 'informing' the proper exercise of judicial discretion rather than governing that discretion), resistance to the official institutionalization of the authority of decision support systems remains strong.

How can we make sense of this deep judicial reluctance to institutionalize judicial decision support systems which are accepted as 'neutral' and 'owned' by judiciaries themselves? What, one might ask, are judiciaries afraid of? Do they have something to hide? In this vein, a deep concern among legal scholars has been with the apparent 'jurisprudential incoherence' of discretionary judicial behaviour. Thus, one explanation for judicial resistance is that judges do not want to institutionalize a decision support system to inform their practice because institutionalization would only expose the lack of an underlying coherent, jurisprudential rationale for judicial decision-making. This claim has considerable attractions, especially to both those legal scholars and computer scientists who (consciously or not) seek to explain judicial behaviour through a 'legalanalytical' approach. In this context a legal-analytical approach views discretionary decision-making as essentially governed or governable by formal rules and principles with legal cases being essentially a combination of discrete 'factors'. Thus, institutionalization becomes more realistic when judges are more jurisprudentially coherent. I propose to examine these claims. I wish to ask the reader to consider the judicial job of doing justice as perhaps less about the application of normative theory or formal rule application to a specific argument or situation than is often supposed by a 'legalanalytical' approach. By way of contrast, I will suggest that the job of judgement is as much, if not more, a performance communicating to a range of different audiences a judicial discourse about an irresolvable tension at the heart of modern law. To put the point another way: the reluctance to institutionalize is less an attempt to conceal jurisprudential incoherence but more about judicial self-perception and its discourse of 'balance' between two visions of justice which modern, liberal law has to straddle. 
Let us examine now specific experiences in the judicial attitude to the institutionalization of their own decision support systems.

\section{Aggregate Information Systems to Support the Use of Judicial Discretion}

Probably more than any other area of judicial decision-making, sentencing represents one of the most difficult, ${ }^{2}$ high-profile and challenging activities. Mindful of judicial axioms that sentencing is an 'art not a science' and that judges are best equipped by knowledge of 'all the facts of each unique case ${ }^{3}$ to determine sentence, much of the research aimed at developing judicial decision support systems has involved aggregate information systems. Although there have been attempts to produce information systems based on case-based reasoning or indeed expert systems none of these has as yet become substantially and routinely operational (and thus a candidate for institutionalization). Rather than being derived from the logic of expert systems, which might aim to produce a single answer to a problem, aggregate sentencing information systems aim to provide a flexible means by which judges can explore the normal patterns of sentencing practice in similar cases. ${ }^{4}$ Below I briefly examine the history and progress of these aggregate information systems for sentencing. The longest-established and most officially entrenched system operates in New South Wales, Australia. This article reveals the carefully crafted ambivalence of the New South Wales Court of Criminal Appeal towards any institutional legitimation of the authority of the Judicial Commission's Judicial Information Research System. Critically considering a liberal-accountability interpretation for this judicial ambivalence, the article suggests instead an alternative understanding of accountability as an inescapably social practice.

The idea of providing sentencers with information on what their colleagues have done when faced with similar cases is not a new one. In 1953, Norval Morris suggested that trial judges be provided with data on sentences imposed so that judges could 'see clearly where they stand in relation to their brethren' (Morris, 1953, p 200 quoted in Frase, 1997, p 366). However, it was not until the 1980s that systems were implemented in Canada by John Hogarth in British Columbia (Hogarth, 1988) and by Tony Doob in other Canadian provinces (Doob and Park, 1987; Doob, 1990) both of which were later abandonned. Following this there have been two jurisdictions which have implemented an SIS and interest from a number of other jurisdictions.

\section{New South Wales}

The New South Wales (NSW) Sentencing Information System (SIS) is administered by the Judicial Commission of New South Wales. Established in 1986 by Parliament, the functions of the Commission are three-fold: to investigate complaints made against Judicial Officers; ${ }^{5}$ to promote consistency of approach in sentencing; and to provide continuing judicial education (Judicial Commission of New South Wales, 1996). The SIS is now a discrete component of a larger 'Judicial Information Research System' (JIRS), which also includes components on industrial, land and environmental law. None the less, the SIS remains the most sophisticated and significant of the modules. All NSW Judicial Officers are connected to the JIRS and the SIS contains a Court of Criminal Appeal (CCA) Judgements Component containing over 3,000 full-text judgements mainly dating from 1990. Cases can be retrieved by case name or by a word search. Allied to this is a CCA summaries component retrieving summaries prepared by staff of the Commission. A hypertext link allows the user 
to view a 'sentencing principles' database which is also prepared by the staff of the Commission. One of the earliest components developed is thought to remain to be the most commonly used: the Sentencing Statistics Component. This in turn is split into Local Court data (with around 170,000 cases over the past two years), and Higher Courts' (District and Supreme Court) data with around 20,000 cases over the last six years. Other SIS components include a legislation; a Facilities Component (concerning the availability of various services and disposals), and a Sentencing Date Calculator (used to calculate the exact date for the commencement and ending of minimum and additional custodial terms).

\section{Scotland}

Partly inspired by a demonstration of the NSW SIS in 1993, the senior judiciary of the High Court in Scotland embarked on an attempt to develop a Scottish SIS. This contains mainly numerical information over the previous seven years with over 6,000 first instance cases and all decisions of the Appeal Court concerning sentence. The system has completed its first phase of implementation and evaluation in which it was piloted for up to 18 months by 18 High Court judges (Tata et al., 1997; Hutton et al., 1996). A second phase of implementation and evaluation is now underway and this will include the development of summaries of all Appeal Court judgements concerning sentencing and the recording of short text written by first instance sentencing judges to complement the information presented in numerical form. Unlike the NSW SIS, the Scottish system has no official institutional home. It is essentially an unofficial collaboration between the senior judiciary and academics at Strathclyde University's Centre for Sentencing Research. While this allows considerable advantage in that creative solutions can be found to judicial concerns rather than simply being tied to official recording practices, it also leaves the Scottish project vulnerable to resource pressures and changes in judicial leadership.

\section{The Netherlands Prototype}

A prototype system known as NOSTRA has been under construction in the northern regions of The Netherlands. An 'input' subsystem in which court clerks collect the data has already been built and is being tested in three courts. The system is limited in scope to around 600 cases of offence categories which, in terms of sentencing, are thought to be relatively uncomplicated. The initiative shown by judges is attributed, at least in part, to judicial concern that if judges themselves do not make efforts to encourage consistency in sentencing then the powerful office of the Public Prosecutor (Downes, 1988; Goriely et al., 1997) will try to commit them to its sentencing guidelines (van der Vinne et al., 1998)

\section{Schild's Prototype Intended for Israeli Judges}

In Israel there has also been academic interest (Schild, 1998) in developing some kind of computer decision support system for judges. More recently the Israeli government has decided to request proposals for the development of a database of previous sentencing practices based mainly on numerical data derived from official police data-sets (Schild, 1998).

\section{Local Initiatives}

In addition to jurisdiction-wide programmes of communicating aggregate information to 
sentencers a variety of informal, ad hoc initiatives occur at local levels. Redbridge Magistrates Court in England, for example, has provided magistrates with an 'audit' (known as 'The Redbridge Examiner') of their sentencing practices (e.g. Faraway, 1997) which provides local magistrates with bulletins of aggregate information on their sentencing practices. The Hampshire Probation Service has worked with the local magistracy to produce a 'sentencing matrix' which aims to be a 'guide to structured decision-making' (Hampshire Probation Service, 1994). To say that these kinds of initiative are in one sense amateurish is not pejorative. Indeed this kind of local ad hoc initiative enjoys strength in its informality and 'ownership' (and thus acceptance) of such feedback (Ashworth, 1997b), but of course it also suffers from the weakness that it may not be institutionalized or as systematic as its own authors may wish. The apparent competition between the interests of systematization and institutionalization as opposed to informality and local judicial ownership is discussed elsewhere (Tata, 1998).

Thus it is possible to detect a growing judicial interest in the development of aggregate sentencing information systems. This is explicable in terms of the way in which legislative guidelines are presented and how SISs present themselves. An SIS is normally seen by judges as a way of heading off pressure for the imposition of guidelines. While legislative guidelines are seen by judges around the world as limiting choice, ownership, and penal neutrality, SISs emphasize values of judicial choice, ownership, and neutrality (Tata, 1998a). In one sense an SIS appears to achieve the same purpose as legislative guidelines, i.e. promoting aggregate consistency vision of justice based (in Weberian terms) on a formal rational vision of justice at the expense of an individualized vision of justice based. However, the means make a difference to the ends. By developing an SIS emphasizing values of judicial ownership, choice, and, neutrality, an SIS is only useful to judges if it is able to be drawn upon by judges as a resource to legitimate both of these visions of jusitice. In other words an SIS is attractive to judges precisely when it is able to straddle these two visions of justice. In thinking about issues in the provision of aggregate data to sentencers a judicial performance which emphasizes the 'balance' between these two competing images of structure in sentencing ('individual case' 'versus the tariff') is implicitly played

out.

\section{Institutional Judicial Legitimation}

Although they have generated rather less judicial resistance and political controversy than numerical and narrative guideline structures, the provision of aggregate data to judges is none the less inevitably an attempt to structure (in perhaps a voluntary fashion) the sentencing process. The increasing affordability, versatility and usability of computer technology means that computers are an increasing part of the furniture of the courts (The Times 22 July 1996). Judges and lawyers now appear to be more reluctant to dismiss the use of computers in legal and judicial practice. Rather, Information Technology is now increasingly perceived to be consonant with power and independence, and in private practice (from where many judges in the common-law world come) as a '... corporate virility symbol ...' (Wall and Johnstone, 1997). As managerialist pressure builds on officials who administer the courts (Bottoms, 1995) to provide evidence of the efficiency, effectiveness and economy (Jones, 1995), so there is perceived to be an imperative to invest in computers to perform a variety of tasks. Coupled with judicial anxieties about independence in sentencing, it becomes possible to anticipate that the courts will come under increasing scrutiny to both justify value for money and to explain how judges are 
responding to concern over disparity. The question is likely to develop from 'could we introduce aggregate information systems?' to 'if other jurisdictions are introducing information systems then why isn't ours?' Yet despite this momentum judges have been deeply reluctant to institutionally legitimate judicial decision support systems.

\section{Lack of Institutional Authority in Canada}

Reflecting on an earlier failed attempt to introduce a Sentencing Information System in Canada, Tony Doob has explained that individual sentencers operate within an environment which does not reward attention to 'current practice'. Judges do not feel a need to obtain information about 'normal practice' except, paradoxically, where they are faced with 'an unusual case'! He found that there were ' ... no indications in any provinces other than Saskatchewan that a reasonable number of people used the system'.

Essentially, then, Doob has argued that from his experience and also, he implies from a similar fate met by Hogarth's earlier system, judges do not perceive there to be a need for this kind of information about 'normal practice' (i.e. an aggregate consistency image of structure). Since judges cannot be coerced into paying attention to such information systems, then judges do not perceive a 'need' for such information. In large part this is because the system carried no institutional authority. It is the Court of Criminal Appeal to which judges pay attention. Doob's argument that sentencers 'do not care to know' what is current practice because 'current practice carries no weight' compared with that of Appeal Court judgements? (Doob, 1990, p 5). Is it inevitable that aggregate information about 'normal practice' will be ignored by judges because such practice has no authority? Doob suggests that if information systems are to be felt to be necessary by judges then it is crucial that they are institutionally legitimized:

Our experience in Saskatchewan, where the project seems to be most successful, suggests that it is important to have the system 'legitimized' by a part of the system that has the authority to do this. I am reasonably sure that it is very important that the prime authority for our involvement in Saskatchewan is the Court of Appeal. (Doob, 1990, p 12)

Without its support and legitimation, decision support systems are in a precarious and vulnerable position. To what extent has this experience been repeated in the longest established Judicial Decision Support System: that run by the New South Wales Judicial Commission?

\section{Institutional Legitimation: Experience in New South Wales}

To what extent has this institutional involvement been possible in NSW and Scotland? In Scotland the initiative for the SIS came from the Lord Justice-Clerk, the second most senior judge in Scotland, with the support of the Lord Justice-General and a number of other senior (Appeal) judges. However, while it has enjoyed this informal senior judicial support, the system has not yet been referred to by the Court of Criminal Appeal and its current status is as an informal, private judicial aid being piloted by judges. While the initiative for the system in NSW has been clearly distinct from that in Scotland, NSW has now built up some experience of the formal institutional attitude of the Appeal Court towards the provision of aggregate data on current normal practice. Wetherburn and Lind (1996) argue that given the traditional reliance on appellate review in sentencing, ' ... the response of the 
NSW Court of Criminal Appeal is likely to prove to pivotal in determining its usage' (Wetherburn and Lind, 1996, p 162).

However, the response of the NSW Court of Criminal Appeal has been marked by a deep ambivalence. The system has been available to both prosecution and defence (albeit on a rather limited basis-see section on access below). There is now reported to be quite a number of Court of Appeal Judgements since 1992 which have made some (mostly minor) reference to aggregate information drawn from the system and normally tabled by the defence or prosecution. Some judgements articulate the claim of 'individualized' sentencing, that it is not reasonable to compare previous sentences to the one at hand, because of the case's 'uniqueness'. Wetherburn and Lind (1996) remarked that, '[a]t this stage the court's attitude to the SIS could best be described as lukewarm'. For example, ${ }^{6}$ in Sams (Kevin James) NSW CCA 14 May 1997 the Court states that it was:

... unpersuaded by the submission that the sentence was manifestly excessive. [Counsel] has referred to some sentencing statistics in his argument before the Court but I must say that I do not find them helpful in this case. (Studdert J)

There was no further explanation of why such aggregate information is not found 'helpful in this case'. However, in another judgement in a Crown Appeal on the same day the same judge in Ross (Steven) NSW CCA 14 May 1997 stated:

I must say I have been troubled by this appeal because the sentence was so plainly a lenient one.

Essentially, though, the success of the appeal depended upon the Crown establishing that in all the circumstances the sentence was manifestly inadequate. In this regard the Crown case was not assisted by sentencing statistics produced to the Court. Those statistics did not illustrate that the sentence here imposed was outside the range. Of course caution has to be used in resorting to such statistics and an appeal cannot be determined simply by reference to statistics of the nature provided here. (Studdert J)

Here, there seem to be two explanations for the Crown case having not been 'assisted' by the aggregate information produced. One explanation suggests that those figures did not show that the original sentence was 'outside the range'. What is intriguing about this statement is not only that it makes no attempt to explain how 'the range' is recognized, but also that the wording studiously avoids implying that the Court either paid attention, or, did not pay attention to the statistics: merely that the Crown's case was 'not assisted' by them. A second explanation seems to lie in the allusion that ' $\ldots$ an appeal cannot be determined simply by reference to statistics of the nature provided here'. Thus there appears also to be concern about the nature of the information, i.e. the ability of the NSW system to provide genuinely similar cases.

This appears to be a rather different criticism from the ability of such systems in principle, to retrieve similar cases as the Canadian experience outlined by Doob might lead one to believe. "[With some exceptions,] my impression is that the six or so "factors" that we arrived at were in very important ways adequate to describe what was a like case' (Doob, 1990, p 5).

However remarks made by Hidden, J. in Duncombe (David Ian) NSW CCA 11 April 1997, suggest that there may be some (at least apparent) concern with the representation of similarity in the NSW system:

[Counsel] submitted that the effective sentence was manifestly excessive in the light of 
Judicial Commission sentencing statistics for the relevant offences and some authority of this Court. Broadly summarised, the statistics show that full-time custodial sentences for offences of receiving stolen property outside the state, and accessory after the fact of larceny of a motor vehicle, are the exception rather than the rule. Frankly the figures are of little use as they are based on a small sample of cases and tell us nothing of the circumstances of them. Both offences embrace a wide variety of activities and frequently do not involve the type of calculated dishonesty characteristic of the applicant's crimes.

If these explanations are to be taken at face-value then it appears that the Court of Appeal may ignore aggregate data not so much 'because current practice carries no weight' (Doob, 1990) but because the system's representation of the similarity of practice may be felt to be inadequate. However, in a judgement passed early in the system's history the Court of Appeal, while indicating its scepticism about the system's ability to identify reasonably similar cases, none the less implicitly acknowledged the value of such aggregate information:

... [W] hat is clear from those [appeal] cases, and from first instance decisions available from the Sentencing Information System, is that a total sentence of five years and nine months for a single charge of supplying amphetamines-even where there is trading involved-is well outside the usual range (which is necessarily a wide one). (Hunt CJ at CL, Hawes (Terrence Robert) NSW CCA 18 February, 1992)

Once again, the concept of a 'usual' or 'normal range' is inescapable in making the necessarily comparative judgements in sentencing, but there is no attempt to articulate what the range is (where it begins and ends) and how it is arrived at. Of particular pertinence is that the Court stated that it used aggregate data to structure (or at least rationalize) its decision. Of further significance, however, would be institutional support and defence of the system. Perhaps in this regard, the judgement in Mayne (John Reginald) NSW CCA 20 December 1996 may be seen as something of a landmark:

In his remarks on sentence his Honour gave short shrift to the submission that he should take into account statistics or sentencing information prepared by the Director of Public Prosecutions or the Judicial Commission. His Honour said: 'I regard such an exercise as of limited use and perhaps even a barren exercise of judicial time in order to produce a false and misleading guide. In my view each case is dependent upon its own facts'.

Perhaps aware of the irony, the Appeal Court then immediately goes on to outline how the first instance sentencer referred to various comparable previous Court of Appeal decisions (which, of course, undermines the first instance sentencer's claim that his approach is to deal with "each case [a]s dependent upon its own facts"'). The judgement continues by congratulating the first instance judge on taking into account what the Court of Appeal had said in 'similar cases', and then turns to his criticism of aggregate data:

However, with respect to his Honour, his Honour should not in my opinion have been so dismissive of the information about sentences imposed for the offence of breaking entering and stealing which had been prepared by the Judicial Commission.... It is of course true that the sentence to be imposed in any particular case depends on the facts of the case. It is also true that care needs to be exercised in using sentencing statistics or information about sentences imposed in other cases. However, it is not the case that consulting statistics or information about sentences have been recently passed for the 
same kind of offence as the judge is sentencing for, is always, or even usually, a barren exercise or a waste of judicial time. Consulting such statistics or information can be useful to a sentencing judge.

The judgement then goes on to refer to an 'inspection' of the SIS and finds that the first instance sentence was excessive since it was '... outside the range of sentences within a sound exercise of his Honour's discretion' (James J).

This may be seen by the Judicial Commission as an important institutional support and defence by the Appeal Court from attack on the value and status of the SIS from first instance sentencers. However, it is also worthy of note that another one of the appeal judges added the remark (amongst other remarks) to that judgement that:

I would not wish to be taken to agreeing, and I don't think it follows from what his Honour says that this is the case, that a sentencing judge must always subordinate his or her views as to the appropriateness of a sentence to the material that is generated by the computers of the Judicial Commission. (Bell, AJ)

The language is disparaging. It is as if, despite all the Judicial Commission's efforts to convince judges otherwise, a judicial belief persists that the SIS data are artificially manufactured or 'generated by the computers' rather than (as the Commission suggests) a simple tool displaying familiar information in an unfamiliar form.

What is perhaps most striking about the attitude of the NSW CCA to the institutional legitimation of aggregate information has been its equivocation and reluctance to commit itself to the authority of such information. The ambivalence is explicit and resolute. To paraphrase: consultation of aggregate sentencing information is neither a futile nor misleading exercise nor is it necessarily always useful! Quite when it is relevant and when not depends, it is said, on the particular circumstances of the sentencing decision. Quite what the circumstances are which determine relevance is not illuminated. In other words, the use of the NSW SIS by the CCA is that it can be used sometimes and not at others. It is used as a selective resource to maintain and legitimate a balance between two visions of justice in judicial discretion: between aggregate consistency and individualized judgement.

Thus the introduction of the use of aggregate sentencing information may not necessarily mean that the balance is tipped towards the aggregate consistency vision of justice as opposed to the individualized vision of justice. Indeed, the most appealing quality of aggregate information systems to judicial opinion seems to be their ability to be used to justify simultaneously both visions of structure and thus maintain a discourse of 'balance' between these two competing visions of justice. Thus, the way in which information is presented by such systems is vital to their credibility. The appeal to judges of such systems tends to lie in the ability to justify the maintenance of a discourse of balance between these two visions. In this sense the appeal lies in the ability to leave the balance between the two visions undisturbed.

\section{Judicial Institutionalization Through Routine Prosecution and Defence Use?}

So far all of the information systems have been primarily intended for the use of sentencers. A critical issue concerns the access to aggregate information systems. Will wider access encourage greater CCA resolution either to legitimate clearly or dismiss the value of aggregate SIS data? The NSW Judicial Commission has allowed access to its SIS to the legal profession. Although the system has been available to the Law Society, Legal Aid/Public 
Defender's Office, Bar Association, and the DPP, only a very limited number of terminals has been provided. In practice, public access and mass media access have not been encouraged. However, following the re-engineering of the NSW SIS to form part of the Commission's new JIRS, negotiations for licensing the system to the profession are underway.

It may be expected that the licensing of the system to the profession will mean that reference to it in court will become a matter of daily routine. It will be difficult for sentencers to ignore information tabled from the system on a daily basis. One of the arguments that had been used in favour of the SIS was that it could result in the reduction in the number of appeals against sentence. The argument has run that defence lawyers would be able to see the 'normal range' of sentences passed in similar cases and most defence lawyers, having seen that the first instance sentence was within the 'normal range', would abandon the 'futile' appeal against sentence. Given the very limited access which the profession has experienced to date, it has of course been difficult to test this hypothesis. However, with the introduction of licensing this theory can be tested, but it is difficult to see how, in itself, defence access to the system will result in a reduction in the number of appeals. Indeed it might just as well result in an increase. For one thing, what is 'the normal range'? A range implies limits, yet as we saw earlier, judges have been reluctant to define its limits. In one case in NSW the Appeal Court came close to attempting a definition and then retreated:

\section{McInerney, J in Sammak (Ali) NSW CCA 2 September 1996 remarked that:}

'The Crown has helpfully provided statistics obtained from the Judicial Commission's Sentencing Information System for the period January 1990 to August 1995. Without going into these statistics in detail, it would appear that in terms of minimum or fixed term sentences for this offence, generally a minimum term of eighteen months falls within the top 12 per cent of cases.

The Crown submits, therefore, that this falls within the range but is at the very top of the range'.

An interesting addition to the NSW SIS is the inclusion of an option which allows the user to identify cases which fall within $80 \%$ of 'the range'. Once this is selected it is interesting to note how closely this begins to appear to be like a flexible numerical guideline approach, although of course without any official sanction.

It is difficult to imagine defence lawyers (at least where fee structures do not encourage it $^{7}$ ), simply looking at one display of the system and accepting it. Rather, the defence would presumably wish to manipulate the choices selected so as to show that the first instance sentence was abnormal. In a sense this is what defence lawyers in appeals against sentence try to do already (i.e. argue that according to a certain construction of similarity the sentence is outside the range). The greater the degree of flexibility in the system to create displays for different case types the easier it will for defence lawyers to use the system to support appeals against sentence. Ironically, flexibility (in any kind of approach to structuring sentencing) is something which judges world-wide appear to favour, and (as in the highly flexible Scottish system) could lead to more appeals (which, as was seen earlier, is, of course, one of the main indicators which judges prefer to use for evaluating their own sentencing performance!). However, it is conceivable that the system could assist in the reduction in the amount of judge-time spent on appeals, but not in itself. Aggregate data 
systems could be used by an appeals filtering body to determine 'futile' appeals which are patently 'within the range'.

We have seen that the Judicial Commission of NSW is taking its first steps towards licensing the JIRS. In Scotland, where judges have a more informal, yet direct, control over their information system, public access questions are eyed anxiously. While the information system is being implemented progressively it is not institutionalized and this allows wider access to be denied at least for the time being. On the one hand it is accepted that much of the information provided is a matter of public record (or at least was at one time), but on the other there is deep anxiety that the system could be used to help to present a slanted, censorious impression of judges. The two visions of justice in modern law in perennial tension are manifested in two visions of justice in judicial discretion.

Is this judicial ambivalence, manifested in both institutional status and public access questions, simply indicative of a characteristic lack of judicial clarity and openness in disclosing what motivates judicial thinking ?

\section{Is Judicial Ambivalence Symptomatic of 'Jurisprudential Incoherence'?}

Aggregate information systems are conceived with one main explicit purpose: calculating the tariff. In his imaginatively critical article about sentencing information systems, David Tait (1998) argues that there are alternative discourses in the way in which such information could be used, and that it is only when these alternatives are examined that the privileged status of 'calculating the tariff' is revealed. While Tait opens out a series of possibilities including hitherto 'excluded discourses' of punishment one of his suggestions lies very much within conventional liberal thinking: in the 'second generation' of SISs, he suggests, judges might be able to record the 'narrative(s)' which most influenced thinking in passing sentence. This would then in turn allow judges to retrieve sentencing patterns on the basis of say, 'just desert', or, 'resolving conflict', etc. and explore the actions taken by other judges using this narrative. This is an intriguing idea. To what extent is this an attempt to ask judges to provide 'reasons' for their sentencing decisions?

The history of attempts to require sentencers to provide penal-philosophical 'reasons' for sentence is not a happy one. 'It is commonly observed that reasons are often expressed as terse formula ... rather than as thought out justifications specific to individual cases ... In short ... reasons tend to become bland, brief and standard' Fitzmaurice and Pease, 1986, p 36). In her study of the 1982 English Criminal Justice Act and in particular Section 1(4) which required sentencers to state the reason (e.g. protection of the public; failure to respond to non-custodial penalties; retribution) for passing a custodial sentence on a young person, Burney (1985) found that in $60 \%$ of the sample the reasons given were incomplete, invalid or not given at all. 'In a story that may be apocryphal, it [was] said that some magistrates courts [had] rubber stamps bearing the legendary "nature and gravity of the offence"' (Fitzmaurice and Pease, 1986, p 36, sic).

Does this failure to articulate clear, open and meaningful reasons simply reflect judicial refusal to accept the need for openness in decision-making (Fox, 1994; Miller, 1989; Parent, 1988)? For example, Doob and Brodeur (1995, p 378) argue that the provision aggregate information to help judges calculate the tariff is 'fundamentally wrong. The problems of sentencing-disparity in particular-can be seen to relate to problems of accountability'. Adapting the work of Day and Klein (1987) Doob and Brodeur argue that it is the lack of a set of shared expectations and common currency of justifications which necessarily means a lack of substantive accountability in sentencing. To rectify this lack of accountability 
Doob and Brodeur call for a sentencing "theory" or a set of guiding principles on sentencing and an explanation of how a sentence followed from the guiding principles' ( $\mathrm{p}$ 384). Doob and Brodeur are far from alone in calling for a more 'coherent' and systematic sentencing practice (e.g. Ashworth, 1995; Henham, 1996, 1997; Fox, 1994; Hutton, 1998; Jobson and Ferguson, 1987).

So why do judges seem to be so reluctant to be pinned down to provide a penal-philosophical explanation of the sentencing decision?

\section{A Lack of 'Jurisprudential Coherence'?}

Thus far, I have concentrated on the value of formal institutional legitimation by Courts of Criminal Appeal. The experience to date from New South Wales suggests that the Appeal Court has been deeply reluctant to state definitively how and even whether an information system should guide the first instance sentencing process. One and perhaps the most likely legal academic interpretation would be that this reluctance suggests an equivocal approach by judges and is indicative of the lack of 'coherence' in sentencing (Lovegrove, 1997, 1999; Schild, 1998). Indeed the suggestion that sentencing lacks 'coherence' is a widely held belief and the 'lack of theoretical coherence' has become even the orthodox academic wisdom. Not only is this lack of coherence an empirical proposition it is also a normative one. It is derived from a specific liberal paradigm about law, justice, and discretionary decision-making. The problem is not that this paradigm is wrong but rather that it necessarily ignores other ways of conceiving of sentencing.

Sentencing is widely described by legal writers as 'incoherent' because of what might be termed 'the philosophical-jursiprudential test of coherence'. In other words, writers have discovered that sentencing decisions do not seem to be methodically, logically, or accurately derived from 'sentencing theory'. By sentencing 'theory' it is invariably meant philosophically derived justifications for punishment. For example, any given decision or set of decisions which do not seem to follow 'principles', such as retribution, denunciation, reparation, general deterrence, individual deterrence, and so on. In their written judgements judges frequently explain their decisions using these philosophically derived terms. Yet, time and again legal scholars demonstrate that both individually and/or collectively judicial logic is flawed; that their application of the aims of punishment is faulty; and that there is no coherent or principled sentencing policy.

It is worth exploring briefly the assumptions made by this philosophical-jurisprudential test of coherence. To some, it may seem strange to prefix the word jurisprudential with 'philosophical'. Indeed, it is common for AI writers to assume that theory about law means jurisprudence which means the philosophy of law (e.g. Gray, 1997; Yannopoulos, 1998; Lovegrove, 1997; Susskind, 1987; Schild, 1998; Zeleznikow and Hunter, 1994; Zeleznikow and Stranieri, 1998). However, Alldridge (1997), for example, takes Suskind's widely read work The Future of Law to task for its anachronistic understanding of the field of jurisprudence and in particular ignoring the crucial contribution of the sociology of law (or sociological jurisprudence). While Suskind's book is not mainly about decision support systems, Alldridge's critique is of the remarkable lack of awareness or understanding in the computers and law field of the long tradition of the sociology of law and its indispensable contribution to legal theory. Alldridge makes the point that much of the writing to date in computers and law has been sustained by a highly positivistic and 
doctrinal characterization of philosophical jurisprudence. This is, Alldridge explains, not so much a matter of accident but of easy convenience:

If you are going to use computers in legal contexts, the pressure which computers generate is towards a rule-bound framework, because it is what they do best. ... The link is a contingent one-there is no logical one, but a practical one. (Alldridge, 1997, p 4)

'Computers and law' thinking has been nourished by an easy mechanical, behaviourist, 'black box' (if $p$ then $q$ ) approach to legal discretion ('a highly formalistic positivism'). Empirical and normative visions of a legal discretionary decision-making process as an essentially mechanical activity (albeit a complex one) is the most convenient vision for many builders of legal decision support systems. Even if it is appreciated that the exercise of legal discretion may not be analytical, sequential or reducible to algebra (Leith, 1998), the normative argument can still be run that it can and ought to be. In this regard a convenient characterization of legal theory as philosophy of law (and a restrictive version at that) is invoked to try to sustain this formalistic positivism.

Dworkin's apparently simple distinction between rules and discretion is often employed to justify discretion as a problem: arbitrary, incoherent, capricious, order-less. Perhaps the most favoured image of discretion which both legal formalists and computer-come-cognitive scientists have is that of Dworkin's celebrated doughnut analogy which neatly captures the attempt to counterpose 'rules versus discretion' so favoured by much of the writing in computers and law. 'Discretion, like the hole in the doughnut, does not exist except as an area left open by a surrounding belt of restriction' (Dworkin, 1977, p 31). In this image discretion is seen as a residual area of rules and significantly an open space (a hole of nothingness) in the doughnut of order. Discretion is opposed to formal rules, order and government. If there are no formal rules then there is discretion which is easily seen as a void, a space in which there is hole in order. "... [T] here is a danger that "discretion" simply becomes a residual category for unexplained variance ...' (Smith, 1981, p 61). If we cannot understand or explain behaviour and reasoning then it is easy to simply see it as some mysterious, ungoverned chaos which needs to be restrained and controlled. However, the sociology of law points towards a different understanding of the nature of legal discretion. Rather than regarding formal law as the main source of order, a sociological approach demonstrates that formal law in fact is only one among many influences on behaviour and may often be marginal or even irrelevant to social order. Rather than the starting point of formal legal rules derived from philosophical-jurisprudential principles, the process of discretionary behaviour can be understood none the less as patterned and predictable. The use of legal discretion can then be appreciated as an inescapably social practice. In this way we might better understand legal 'discretion' as largely a chimera: there may be technical-legal space for substantive choice but that choice is substantially determined and governed by informal, social-behavioural, codes of expectations (contextual social 'rules').

So, given insight from the sociology of law and its rich empirical literature over the last 50 years, how should we understand judges' apparent reluctance to explain coherently their sentencing approach? First, we should question the easy assumption that because judicial behaviour does not conform to legal principles and 'the philosophical jurisprudence test' that behaviour is therefore order-less, chaotic, incoherent, and unpredictable. For many writers the lack of coherence they identify in sentencing is a legal-philosophical incoherence: in particular an incoherence in judicial explanation for sentence in terms of the 
moral-philosophical 'justification' for punishment. This incoherence is, as Doob and Brodeur argue fundamentally a lack of accountability. However, this is to conceive of judicial accounts as mere mechanistic reports of 'what happened in their mind'. I would suggest instead that the reason why, judges' explanations are so wanting according to the philosophical-jurisprudential yardstick is because their judicial explanation is essentially a socially pragmatic exercise.

Writing about the news media as an integral part of criminal justice, Ericson (1995) argues for two conceptions of the notion of 'accountability'. One view is of accountability as entailing an obligation to give an account of activities within one's ambit of responsibility. This we might call 'liberal-legal accountability' with its concern for chains of command and requirement to give an explanation of one's actions to a superior. Another understanding has led to the coinage of the term,

account ability: the capacity to provide a record of activities that explains them in a credible manner so that they appear to satisfy the rights and obligations of accountability. Clearly, the formal obligation to give an account does not ensure uniformity in the ability to give an account. The ability varies, for example, by what has to be accounted for; who makes the demand ...; who is the intended audience ...; and the spatial, social, cultural and communications format capacities to make an account. (Ericson, 1995, p

'Account ability' is about satisfying various socially contingent needs within a sphere of discourse. In their everyday interactions human beings are 'reflexive, knowledgeable agents who perpetually adjust their senses of rights and obligations to organizational contingencies such as knowledge resources, ... political interests, authority structures, communication formats and occupational cultures' (Ericson, 1995, p 136). In this way (and since every account necessarily requires selection) 'account ability' necessarily invokes the continual practice of revelation and secrecy.

So rather than simply seeing the giving of penal-philosophical reasons as a means of revealing the 'true' or 'real' reasons for a decision and providing greater transparency the focus of study is shifted onto questions of negotiation, context, perceived audience expectations and so on. So, for example, judges should be expected to give a rather different style of account of sentencing practice to different audiences: each other; to themselves; academic researchers. ${ }^{8}$ In this way, rather than seeing the provision of sentencing 'reasons' for sentencing decisions as a simple, posited, mechanistic action, we might instead view reason-giving as a necessarily shifting, subtle and negotiated process whose representation of decision-making is contingent on the social situation. Thus, reasons which are given in open court are defensible rather than unmediated 'truth'.

While judges tend to 'explain' their decisions by a mention of philosophical justifications for punishment after a narration of the 'facts' of the case, there tends to be relatively little, if any, enunciation of how the decision process moved from 'the facts' to the philosophical justification to the decision. Informed by Ericson's understanding of 'account ability' to sentencing, the presentation of reasons for judgements is about the performance of the role of being seen to endeavour to 'balance' various interests, expectations, contexts and audiences rather than satisfying simply the rigours of legal-analytical expectations.

This is well illustrated in the way that appeal court judgements typically perform a role of communicating a balancing role between two competing visions of justice in the judicial discourse of sentencing. Sentencing researchers will be well familiar with the judicial mantra that sentencing is 'a balance between the tariff and the individual facts and 
circumstances of each unique case'. As researchers it would be easy to scoff at the obvious illogic of this kind of statement. First, it is not possible to use experience to judge something which is genuinely 'unique'. Secondly, we know from research that as in other discretionary realms, the criminal process re-presents cases to judges as merely variants of a limited and finite range of standardized, typified plots rather than unique individual facts (Tata, 1997). Yet, the appreciation of 'account ability' suggests that judgement-writing is as much, perhaps more, about satisfying audiences and negotiating expectations (albeit routinely and barely consciously). In this sense, then, the judicial mantra of 'balance' tells us more about the performance of balance which judges are trying to communicate than some supposed transparent revelation of reasoning to come to a decision. This balance which judges reiterate is a judicial discourse of balance between two visions of justice in sentencing. In Weberian terms it is a balance between 'formal-rational' law (in sentencing with its concern for rational calculation, formal rules, openness and predictability) and 'substantive-irrational' law with its concern for individual cases and apparent uniqueness.' So in this way Appeal Court Judgements are able to appeal to both of these visions of justice in sentencing. In abstract jurisprudential theory these visions are in tension with each other and their simultaneous operation must be 'incoherent'. In social practice, however, a recognition that Appeal Court Judgements necessarily are also about 'account ability' means that judgement-writing becomes comprehensible as a performance of balance between two visions of justice at the heart of modern law.

\section{Conclusions}

I have suggested that the deep reluctance and inability to provide explicitly and transparently logically reasoned judgements should not, in itself, be understood as the attempt by a conservative judiciary to maintain mystique about the judicial decision process. It is highly questionable that sentencers operate (or can operate) according to philosophical theories of punishment to 'explain' sentencing. True, judges are normally required to provide an account for their decisions to a variety of audiences (the court at the time; an official 'Opinion'; or sometimes to the mass media), but this is quite distinct from simply reporting the essential unedited consciousness of thinking in deciding sentence. As scholars of the judicial decision process, we should ask ourselves whether the judicial account for a decision is or can be the complete, fixed explanation of judicial consciousness. Rather I would suggest that these accounts are necessarily mediated, constructed and reconstructed according to the audience and requirements of the ability to account for the decision.

Every act of publicity for accountability is also an act of selection and distortion in which some things are left out and some alternative formulations are ignored ... Communications do not stand apart from reality. There is not first reality and then second communication about it. Communications participate in the formation and change of reality. Facts arise out of communication practices .... (Ericson, 1995, pp 137-144).

In this conception, 'account ability' is seen as necessarily a selective and negotiative phenomenon rather than being about a straightforward revelation of a notional objective truth. Inevitably, it is not possible to explain or articulate the full and unmediated pattern of consciousness of the sentencer. Necessarily this must be a selective process mediated by the context of giving the account.

In this light, the expectation that the judge (or indeed any discretionary decision-maker) 
ought or can apply a sentencing theory grounded in philosophical justifications for punishment is problematic. The account supplied by a sentencer cannot be a simple reflection of how she structured the decision, but necessarily was socially mediated by the particular context.

The point is that there are always competing audiences, expectations, purposes, revelations and secrecy. To expect or suppose as Lovegrove (1999, p 67) most emphatically does, that judges' explanations are some open, full comprehensive revelation of their consciousness seems to assume the judge as a 'black-box' machine, albeit a sophisticated one. This black-box conception allows for very little understanding of the social production and organization of justice as opposed to a cognitive and ultimately mechanistic model of judicial thought.

The marked judicial ambivalence towards the institutionalization of aggregate decision support systems seems at least in large part to be driven by a concern to be seen to perform a role which balances formal and substantive visions of justice. A decision support system is considered most acceptable when it is regarded by judges as flexible. Flexibility allows judges to flip literally between these two visions of justice in their ability to 'account' for their decisions: between the standard and the particular; the general and the individual; and thus maintain a performance of careful 'balance'-resolute in its ambivalence.

\section{Notes}

1 I would like to acknowledge the following people for their helpful comments on this article and its ideas: Tony Doob, Simon Halliday, Neil Hutton, Ernie Schmatt, and Ivan Potas. In addition I would like to thank the anonymous external referees of this article for their constructive comments. An earlier version of this paper was presented to the Second International Workshop on Judicial Decision Support Systems (held under the auspices of the International Conference on Artificial Intelligence \& Law), June 1999, Oslo. I am grateful to delegates for the lively and constructive discussion which ensued.

2 By 'difficulty' I specifically mean uncertainty rather than logical or technical difficulty. As typical of discretionary judgement, difficulty lies mainly in the uncertainty of the task rather than abstract intellectual difficulty (see van Duyne, 1987).

3 The non-sense of the oft-repeated claim that 'each case is unique and turns on its own facts' and the inescapably comparative and socially constructed nature of judgement is dealt with elsewhere (e.g. Tata, 1997; Hood, 1968).

4 The term 'similar cases' is of course a key issue which I have addressed at length elsewhere. See for example, Tata $(1997,1998)$.

5 This term incorporates magistrates as well as judges.

6 The examples which are discussed are drawn from a search of the NSW system and are largely unreported judgements.

7 For a discussion of recent research into the fee structures in criminal legal aid work see Goriely et al. (1997) and Tata (1998b).

8 Paul Maharg's critique of the Toumlin Dialogue Game reveals parallel difficulties in the context of legal education: 'there is curiously little agency, intentionality or context ... Who is the game for, and who will play it? In which social or legal context will it be used? If social context is essential to law's performative nature, which context and which audience are envisaged? These are important criteria, which affect a user's manipulation of the model of legal practice.... there is much more to legal argumentation than a reduction of it to formal characteristics. Toumlin may have given us a generic description of argument, which can be applied to the product of legal argumentation; but does it describe the process by which expert lawyers dispute? Moreover, despite its promise of dialogism, there is arguably little room in the Toumlin model for the rhetoric of law as enacted in documents or in courts' (Maharg, 2000, pp 163-164 original emphasis retained). 
9 I am using the terms 'rational' and 'irrational' in the specific Weberian senses rather than in their popular usage of rational as logical and intelligent and 'irrational' as illogical or 'mad'. (For further discussion on Weber's different 'ideal-types' of rationality applied to sentencing see Hutton, 1995.)

\section{References}

P Alldridge 'Anoraks among the suits and jeans: computers, law and the legal academy' Journal of Law, Information and Technology No 2, 1997. http:elj.warwick.ac.uk/jilt/wip/97_2aldr/

R Anderson 'Development of structured sentencing simulation' Social Science Computer Review 1993.

A Ashworth 'Sentencing by computer: what next ?' Criminal Law Review Vol 44, pp 153-154, 1997a.

A Ashworth 'The value of empirical research in criminal justice' Criminal Law Review Vol 44, pp 533-554, 1997b.

A Ashworth Sentencing and Criminal Justice (2nd edn), Butterworths, London, 1995.

A Ashworth and M Hough 'Sentencing and the climate of public opinion' Criminal Law Review Vol 43, pp 776-787, 1996.

A Ashworth, E Genders, G Mansfield, J Peay and E Player Sentencing in the Crown Court: report of an exploratory study, Occasional Paper No 10, University of Oxford Centre for Criminological Research, Oxford, 1984.

$\mathrm{R}$ Baldwin 'Discretionary justice and the development of policy', in DJ Galligan (ed) A Reader on Administrative Law, Oxford University Press, Oxford, 1996.

A Bottoms 'The philosophy and politics of punishment and sentencing' in C Clarkson and M Morgan (eds) The Politics of Sentencing Reform, Clarendon Press, Oxford, 1995.

I Brownlee 'Taking the strait-jacket off: persistence and distribution of punishment in England and Wales’ Legal Studies, Vol. 14, No. 3, 1994.

E Burney, 'All things to all men: justifying custody under the 1982 Act' Criminal Law Review Vol 32, p 284, 1985.

K-C Davis Discretionary Justice: A Preliminary Inquiry, 1969.

P Day and R Klein Accountability: five public sector services, Tavistock, London, 1987.

P Derbeyshire 'An essay on the importance and neglect of the magistracy' CLR, 1995.

A Doob 'Evaluation of a computerized sentencing aid' Report of the Select Committee of Experts on Sentencing, European Committee on Crime Problems, Council of Europe, Strasbourg, 1990.

A Doob 'The United States Sentencing Commission Guidelines: if you don't know where you are going, you might not get there' in C Clarkson and R Morgan (eds) The Politics of Sentencing Reform, Oxford University Press, Oxford, 1995.

A Doob and J-P Brodeur 'Achieving accountability in sentencing' in P Stenning (ed) Accountability for Criminal Justice, University of Toronto Press, Toronto, 1995.

A Doob and N Park 'Computerised sentencing information for judges: an aid to the sentencing process' Criminal Law Quarterly, Vol 30, p 54, 1987.

R Dworkin Taking Rights Seriously, Harvard University Press, Cambridge, MA, 1977.

$\mathrm{N}$ Duncan 'The skill of learning: implications of the ACLEC first report for teaching skills on undergraduate law courses' Web Journal of Current Legal Issues No 5, 1997. http:// www.ncl.ac.uk:80/ nlawwww/1997

R Ericson 'The news media and account ability' in P Stenning (ed) Accountability for Criminal Justice, University of Toronto Press, Toronto, 1995.

C Fitzmaurice and K Pease The Psychology of Judicial Sentencing, Manchester University Press, Manchester, 1986.

R Fox 'The meaning of proportionality in sentencing' Melbourne University Law Reviews Vol. 19 No. 3 pp. 489-511, 1994.

M Frankel Criminal Sentences: law without order, Hill \& Wang, New York, 1972.

R Frase 'Sentencing principles' in M Tonry (ed) Crime and Justice: a review of research Vol 22, 1997. 
R Frase 'Sentencing guidelines in Minnesota and other American states: a progress report' in C Clarkson, and R Morgan (eds) The Politics of Sentencing Reform, Oxford University Press, Oxford, 1995.

T Goriely, C Tata, and A Paterson Expenditure on Criminal Legal Aid: report of the comparative pilot study of England and Wales, the Netherlands, and Scotland, Scottish Office, Edinburgh, 1997.

Hampshire Probation Service Targeting Matrix: a guide to structured decision-making for practitioners (Criminal Justice Act 1991 as Amended by the Criminal Justice Act 1993, Hampshire Probation Service, 1994.

P Hassett 'Can expert system technology contribute to improved bail decisions?' International Journal of Law and Information Technology Vol 2, 1993.

K Hawkins and R Baldwin 'Discretionary justice: Davis reconsidered' Public Law Winter, pp 570-599.

$\mathrm{C}$ Hedderman and L Gelsthorpe (eds) Understanding the Sentencing of Women: Home Office research study No 170, Home Office, London, 1997.

R Henham 'Sentencing policy and the role of the court of appeal' Howard Journal Criminal Justice Vol. 34, pp 218-227, 1995.

R Henham Criminal Justice and Sentencing Policy Dartmouth, Aldershot, 1996.

$\mathrm{R}$ Henham 'Protective sentences: ethics, rights and sentencing policy' International Journal of the Sociology of Law Vol 25, No 1, pp 45-64, 1997.

R Henham 'Sentencing policy and the abolition of parole and early release' International Journal of the Sociology of Law Vol 25, pp 337-361, 1998a.

R Henham 'Making sense of the Crime (Sentences) Act 1997' Modern Law Review Vol 61, No 2, pp 223-235, 1998b.

R Hood in collaboration with G Cordovill Race and Sentencing, Clarendon Press, Oxford, 1992.

M Hough 'People talking about punishment' Howard Journal of Criminal Justice Vol 35, pp 191-214, 1996.

B Hudson 'Beyond proportionate punishment: difficult cases and the 1991' Criminal Justice Act. Crime, Law and Social Change Vol 22, pp 59-78, 1995.

$\mathrm{N}$ Hutton 'Sentencing, rationality and computer technology' Journal of Law and Society Vol 22, No 4, pp 549-570, 1996.

N Hutton, A Paterson, C Tata and J Wilson A Prototype Sentencing Information System for the High Court of Justiciary: report of the study of feasibility, HMSO/Scottish Office Central Research Unit, Edinburgh, 1996.

$\mathrm{N}$ Jareborg 'Swedish sentencing reform' in C Clarkson and R Morgan (eds) The Politics of Sentencing Reform, Oxford University Press, Oxford, 1995.

$\mathrm{K}$ Jobson and G Ferguson 'Towards a revised sentencing structure for Canada' The Canadian Bar Review Vol 66, No 1, pp 1-48, 1987.

C Jones 'Auditing criminal justice' British Journal of Criminology Vol 33, 1993.

Judicial Commission of New South Wales Annual Reports, Judicial Commission of New South Wales, Sydney, 1995.

Judicial Commission of New South Wales Annual Reports, Judicial Commission of New South Wales, Sydney, 1996.

Judicial Commission of New South Wales Annual Reports, Judicial Commission of New South Wales, Sydney, 1997.

D Kelly Criminal Sentences, T\&T Clark, Edinburgh, 1993.

P Leith 'The judge and the computer: how best decision support?' Artificial Intelligence and Law: an International Journal Vol. 6, Nos 2-4, pp 289-309, 1998.

A Lovegrove The Framework of Judicial Sentencing, Cambridge University Press, Cambridge, 1997.

A Lovegrove 'Statistical information systems as a means to consistency and rationality in sentencing' International Journal of Law and Information Technology Vol 7, No 1, pp 31-72, 1999.

S Lloyd-Bostock Law in Practice: applications of psychology to legal decision-making and legal skills, British Psychological Society/Routledge, London, 1988.

Magistrates Association Sentencing Guidelines (April Issue), Magistrates’ Association, London, 1997. 
P Maharg (2000) 'Law, learning, technology: reiving ower the borders' International Review of Law, Computers and Technology Vol. 14, No. 2, pp 155-170, 2000.

K Malleson The New Judiciary: effects of expansionism and activism, Ashgate, Aldershot, 1999.

$\mathrm{K}$ Malleson 'Judicial training and performance appraisal: the problem of judicial independence' Modern Law Review Vol 60, pp 655-667, 1997.

M Miller 'Rehabilitating the federal sentencing guidelines' Judicature: the Journal of the American Judicature Society Vol 78, No 4, 1995.

M Miller 'Guidelines are not enough: the need for written sentencing opinions' Behaviorial Science and the Law Vol 7, No 1, 1989.

I Nagel, 'Structuring sentencing discretion: the new federal sentencing guidelines' Journal of Criminal Law and Criminology Vol 80, pp 299-317, 1990.

I Nagel and B Johnson 'The role of gender in a structured sentencing system: equal treatment, policy choices, and the sentencing of female offenders under the United States sentencing guidelines' The Journal of Criminal Law and Criminology Vol 85, No 1, pp 181-221, 1994.

D Nelken The Limits of the Legal Process: a study of landlords and crime, Academic Press, New York, 1983.

CGB Nicholson Sentencing: law and practice in Scotland, W. Green/Sweet and Maxwell, Edinburgh, 1992.

CGB Nicholson The Law and Practice of Sentencing in Scotland, W. Green, Edinburgh, 1981.

A Oskamp, M Tragter, C Groendijk 'AI and law: what about the future?' Artificial Intelligence and Law: International Journal Vol 3, pp 309-215, 1995.

D Parent Structuring Criminal Sentences: the evolution of Minnesota's sentencing guidelines, Butterworth Legal Publishers, London, 1988.

H Parker, M Sumner and A Jarvis Unmasking the Magistrates, Open University Press, Milton Keynes, 1989.

I Potas 'Consistency of approach in sentencing: a description of the Judicial Commission's sentencing information system' Paper delivered to the Workshop on 'Decision Support Systems' Under the Auspices of The International Conference on Artificial Intelligence and Law, Melbourne, 1997.

D-M Provine 'Too many black men: the sentencing judge's dilemma' Law and Social Inquiry Vol 23, No 4, pp 823-856, 1998.

U Schild 'Statistical information systems for sentencing: a cookbook' International Journal of Law and Information Technology Vol 6, No 2, 1998.

G Smith 'Discretionary decision-making in social work' in M Adler and S Asquith (eds) Discretion and Welfare, Heinemann Educational Books, London, 1981, pp 47-69.

D Tait 'Judges and jukeboxes' International Journal of Law and Information Technology Vol 6, No 2, 1998.

$\mathrm{R}$ Tarling Sentencing Practice in Magistrates Courts, Home Office Research Unit, Study No. 56, HMSO, London, 1979.

C Tata 'Conceptions and representations of the sentencing decision process' Journal of Law and Society Vol 24, No 3, pp 395-420, 1997.

$\mathrm{C}$ Tata 'The application of judicial intelligence and rules to systems supporting discretionary judicial decision-making' Artificial Intelligence and Law: an International Journal Vol 6, Nos 2-4, pp 199-225, 1998a.

C Tata "Neutrality", "choice", and "ownership" in the construction, use, and adaptation of judicial decision support systems' International Journal of Law and Information Technology Vol 6, No 2, 1998 b.

C Tata "The construction of "comparison" in legal aid spending: the promise and perils of a jurisdiction-centred approach to (international) legal aid research' in F Regan, T Goriely, A Paterson and D. Flemming (eds) The Transformation of Legal Aid: historical and comparative studies, Oxford University Press, Oxford, 1999, pp 133-159.

C Tata and N Hutton 'What "rules" in sentencing?' The International Journal of the Sociology of Law, 1998. 
C Tata, N Hutton, J Wilson and I Hughson A Sentencing Information System for the High Court of Justiciary of Scotland: report of the study of the first phase of implementation and enhancement, Scottish Courts Administration, Edinburgh, 1997.

D Thomas 'Sentencing reform: England and Wales' in C Clarkson and R Morgan (eds) The Politics of Sentencing Reform, Oxford University Press, Oxford, 1995.

M Tonry Sentencing Matters, Oxford University Press, Oxford, 1996.

M Tonry and K Hatlestad (eds) Sentencing Reform in Overcrowded Times: a comparative perspective, Oxford University Press, New York, 1997.

J van der Vinne, WI van Zwol, and M Karnekamp “NOSTRA” project report' International Journal of Law and Information Technology Vol 6, No 2, 1998.

N Walker and N Padfield Sentencing: theory, law, and practice, Butterworths, London, 1996.

D Wall and J Johnstone 'The industrialization of legal practice and the rise of the new electric lawyer: the impact of information technology upon legal practice in the UK' International Journal of the Sociology of Law Vol 25, No 2, pp 95-116, 1997.

D Wetherburn and B Lind 'Sentence disparity, judge shopping and trial court delay' Australian and New Zealand Journal of Criminology Vol 29, No. 2, 1996.

D Warner 'The role of neural networks in law machine development' Rutgers Computers and Technology Law Journal Vol 16, pp 129-144, 1990.

J Zeleznikow and D Hunter Building Intelligent Legal Information Systems (Computer Law Series 13), Kluwer Law and Taxation Publishers, Dordrecht, 1994.

J Zeleznikow and A Stranieri 'Split-Up: an intelligent decision support system which provides advice on property division following divorce' International Journal of Law and Information Technology Vol 6, No 2, pp 190-213, 1998.

J Zeleznikow and A Stranieri 'Modelling discretion in the Split-Up system' Paper presented at the Workshop on Judicial Decision Support Systems, The Sixth International Conference on Artificial Intelligence and Law, Melbourne, 1997. 